\title{
Aneurysm of a. gastroduodenalis as a source of gastric hemorrhage
}

\author{
A. I. Sukhodolia, S.A. Sukhodolia, O. V. Gryshchuk, V.P. Mosiichuk, V. D. Tokarchuk
}

National Pirogov Memorial Medical University, Vinnytsya

\section{Аневризма шлунково-дванадцятипалокишкової артерії як причина шлункової кровотечі}

\author{
А. І. Суходоля, С. А. Суходоля, О. В. Грищук, В. П. Мосійчук, В. Д. Токарчук \\ Вінницький національний медичний університет імені М. І. Пирогова
}

\begin{abstract}
Visceral artery aneurysm (VAA) is a rare pathology, characterized by combination of asymptomatic course with dangerous sudden complications: rupture and intraperitoneal or gastrointestinal bleeding. In most patients, VAA is diagnosed as an accidental finding during examination for another pathology.

Due to the widespread use of the computed tomography and magnetic resonance imaging, ultrasound, CT angiography, the diagnosis of vascular pathology has become more accurate [1]. VAA is classified by etiology (congenital or acquired), localization, shape (sac-like and spindle-shaped), morphology (true and false).

Most commonly the VAA is localized in splenic artery (60\%), hepatic artery (20\%), superior mesenteric artery ( 5 - 7\%), celiac trunk (3 - 4\%), and gastroduodenal artery (2 4\%) $[2-6]$.

In a literature review by E. Moore et al. [6], the authors have reported that VAA is equally common in women and men, and the average age of the patients constitutes $58 \mathrm{yrs}$ old. Here we present a clinical observation of successful
\end{abstract}

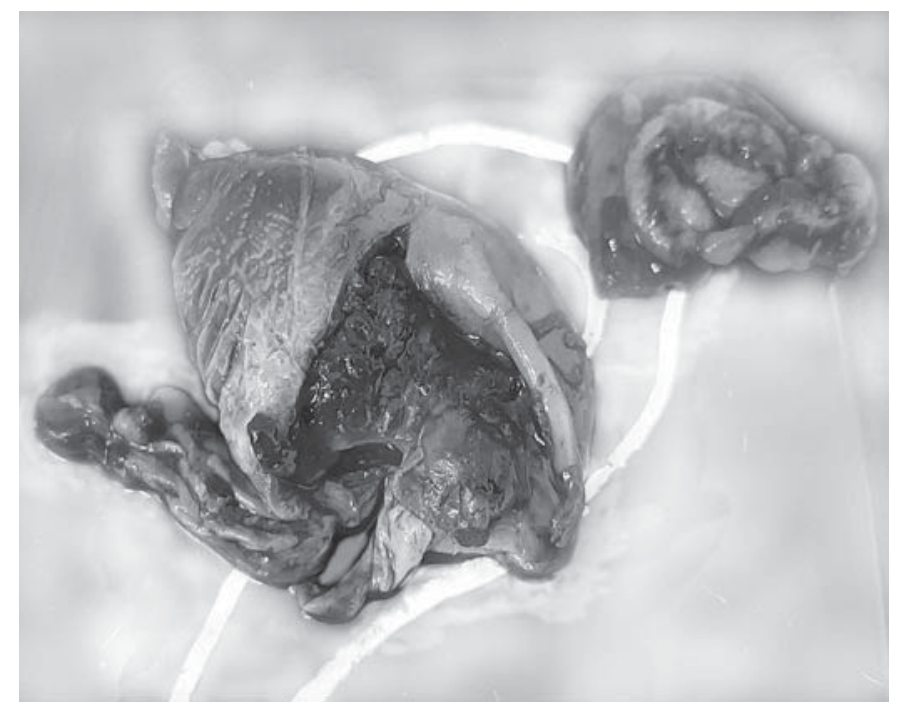

Аневризма шлунково-дванадиятипалокишкової артерії з тромбом. treatment of patient with the gastroduodenal artery aneurysm, complicated by penetration into the gastric lumen and massive gastrointestinal bleeding.

A 50 year old man was admitted to our hospital on November 15, 2020 with complaints of general weakness, dizziness, vomiting with "coffee grounds", black stools, tinnitus, pale skin, cold sticky sweat, dry mouth. These complaints have appeared suddenly a day ago and he was brought into the central district hospital, where he was diagnosed with polyps of gastric small curvature; stopped gastrointestinal bleeding, type IIB, according to the Forest scale; acute post-hemorrhagic anemia of extremely severe degree. General blood test: hemoglobin $58 \mathrm{~g} /$ l; erythrocytes 1.8 1012 / 1; hematocrit 18\%. Esophagogastroduodenoscopy data: esophagus freely passable, mucosa was pale pink. In the stomach on a small curvature a sessile polyp, measuring $1.5 \mathrm{~cm}$, with a thrombus on its tip. The mucosa is anemic. In the stomach, there was a large amount of the hydrochloric acid hematin.

Due to high probability of the gastrointestinal bleeding recurrence and the development of hemorrhagic shock, the patient was hospitalized for further examination and surgical treatment. Esophagogastroduodenoscopy data: fixed blood clot on the small curvature of gastric body with suspected polypoid formation. General blood test: hemoglobin $67 \mathrm{~g} / \mathrm{l}$; erythrocytes $2.38 \times 10^{12} / \mathrm{l}$; hematocrit $20.1 \%$.

The surgery was performed urgently: subtotal distal gastrectomy in accordance to Billroth-II in the Hofmeister-Finsterer modification.

Intraoperatively, it was established, that the patient had an aneurysm of the gastroduodenal artery with a diameter of $3 \mathrm{~cm}$ and a length of up to $5 \mathrm{~cm}$, which penetrates the stomach along a small curvature with a defect up to $4 \mathrm{~cm}$ in diameter (see figure). The rupture site was thrombosed, that's why the mobilization attempt have ended with an active bleeding from the proximal end of the unchanged gastroduodenal artery. The bleeding source was successfully eliminated by suturing of proximal and distal ends of the vessel. The aneurysmal sac and resected stomach were sent for histopathological examination. 
Given the severity of the condition, the volume of surgery and hemodynamic parameters, intraoperatively and in the postoperative period the patient have received the blood and the fresh-frozen plasma transfusion. The severity of the patient's condition was aggravated by concomitant decompensated diabetes mellitus Type II (the blood glucose 21.5 mmol / 1 at the time of hospitalization). Hyperglycemia was corrected by treatment with a short-acting insulin, while doing a subsequent control of the blood glucose levels. In postoperative period, the patient's general condition was stable, without complications. The patient was discharged in satisfactory condition on the 8th postoperative day.

Pathology report: part of the stomach with perforated ulcerative defect with fibrotic edges, the leukocyte shaft, fibrinous-leukocyte layers. The ulcer defect turns into a saclike hollow formation with layered walls, represented by all layers of the artery wall, characteristic for the muscle-type arteries, with the fibrous, partially necrotized tissue, which is unevenly permeated with blood with accumulations of leukocytes and fibrinous-leukocytes.

\section{Conclusion}

The clinical case, adduced above, demonstrates the rare pathology of VAA, the complexity of its diagnosis and radicalism of surgical treatment.

Finding. At the expense of the authors.

Contribution of autbors. The authors contributed to this manuscript equally.

Conflict of interest. The authors who participated in the study stated that they had no conflict of interest regarding this manuscript.

Consent to publication. All authors have read and approved the final version of the manuscript. All authors have agreed to publish the manuscript.

\section{References}

1. Pulli R, Dorigo W, Troisi N, Pratesi G, Innocenti AA, Pratesi C. Surgical treatment of visceral artery aneurysms: A 25-year experience. J Vasc Surg. 2008 Aug;48(2):334-42. doi: 10.1016/j.jvs.2008.03.043. PMID: 18644480.

2. Stepanova YuA, Karmazanovsky GG, Kokov LS, Tsygankov VN. True Aneurysms of Visceral Arteries: Diagnosis and Treatment Using Radiology Techniques. Doctor.Ru. 2015;1(11):46-52. Russian.

3. Stanley J.C., Whitehouse W.M. Jr. Splanchnic artery aneurysms. In: Rutherford RB, ed. Vascular surgery. 6th ed. Philadelphia. Elsevier Saunders. 2005; 6: 1565-81. ISBN: 9789997626769

4. Chong WW, Tan SG, Htoo MM. Endovascular treatment of gastroduodenal artery aneurysm. Asian Cardiovasc Thorac Ann. 2008 Jan;16(1):68-72. doi: 10.1177/021849230801600118. PMID: 18245712 .

5. Battula N, Malireddy K, Madanur M, Srinivasan P, Karani J, Rela M. True giant aneurysm of gastroduodenal artery. Int J Surg. 2008 Dec;6(6):459-61. doi: 10.1016/j.ijsu.2006.05.010. Epub 2006 Jun 21. PMID: 19059144.

6. Moore E, Matthews MR, Minion DJ, Quick R, Schwarcz TH, Loh FK, et al. Surgical management of peripancreatic arterial aneurysms. J Vasc Surg. 2004 Aug;40(2):247-53. doi: 10.1016/j.jvs.2004.03.045. PMID: 15297817.

Received: 08.12.2020 